\title{
Að pýða bundið mál Shakespeares fyrir leiksvið
}

ér á eftir er ætlun mín að fara nokkrum orðum um sumar pær áskoranir sem ég stóð frammi fyrir pegar ég pýddi leikrit Williams Shakespeares Rikharð III að beiðni Borgarleikhússins, en uppsetning verksins var jólasýning leikhússins árið 2018. Rétt er að taka fram að sá texti sem Borgarleikhúsið fól mér að pýða var ný gerð af leikriti Shakespeares sem Brynhildur Guðjónsdóttir, leikstjóri sýningarinnar, og Hrafnhildur Hagalín dramatúrg höfðu mótað. Til hliðsjónar við vinnu mína hafði ég útgáfur af verkinu í heild en minn frumtexti var handrit par sem Brynhildur og Hrafnhildur höfðu stytt verkið og umraðað ýmsu í textanum. Mér fannst strax frá upphafi sýn Brynhildar og Hrafnhildar á verkið mjög áhugaverð og hin nýja gerð peirra vel heppnuð. Pær vildu leggja áherslu á pátt kvenna í sögunni um Ríkharð og höfðu fellt út ákveðna hluta verksins, stytt kafla, strikað út braglínur og hluta úr braglínum og fært texta á milli persóna. Síđast en ekki síst höfðu pær gefið Elísabetu, bróðurdóttur Ríkharðs, rödd en hún skiptir máli í leikriti Shakespeares pótt hún sé ekki ein af persónum verksins og aðeins sé vísað til hennar í samtölum annarra. Í uppsetningu Borgarleikhússins birtist hún á sviðinu og henni er lagður í munn texti frá öðrum persónum. Pað gefur bví auga leið að ef býðing mín er borin saman við frumtexta Shakespeares kemur fljótt í ljós að ýmislegt vantar í íslenska textann og eins að í pýðingunni skjóta setningar skáldsins upp kollinum á stöðum par sem pær er ekki að finna í frumtextanum.

Á peim rúmlega tuttugu árum sem ég hef fengist við að pýða leikrit hef ég fyrst og fremst pýtt leikrit nútímahöfunda sem gerast í 
samtímanum, ef undan er skilið The Crucible eftir Arthur Miller sem ég nefndi Eldraunina og var leikið í pjóðleikhúsinu árið 2014, en pað verk gerist á sautjándu öld. Pýðing Ríkhards III er pví ólík öðrum verkefnum sem ég hef glímt við. Meginmunurinn liggur vitaskuld í peim áskorunum sem fylgja pví að pýða leiktexta á bundnu máli. Í peirri vinnu nýttist mér vel að ég hef töluverða reynslu af bví að̀ yrkja á bundnu máli og ég hef sent frá mér ljóðabækur með háttbundnum kvæðum.

Pýðing bundins máls á erlendri tungu yfir á bundið mál á íslensku, í samræmi við íslenska braghefð, kallar á að pýðandinn einbeiti sér að pví að fanga kjarnann í hugsun höfundarins. Slík pýðing er alltaf að talsverðu leyti endursköpun. Pýðandinn parf óhjákvæmilega að enduryrkja frumtextann, ef svo má að orði komast, til að mæta kröfum formsins. En um leið finnst mér skipta miklu máli að vera hugsun skáldsins trúr, nálgast texta höfundar af virðingu og ákveðinni auðmýkt. Hið bundna mál setur býðandanum vissulega skorður, en ekki má gleyma pví að sá bragarháttur sem skáldið sjálft beitti setti pví líka skorður á sínum tíma. Auðvitað var Shakespeare ekki alveg frjáls pegar hann orðaði hugsanir sínar heldur varð hann að fella pær að bragarhættinum. Orðnotkun hans stjórnast af forminu að ákveðnu leyti. Ég hef stundum leyft mér að nota pá líkingu að pýðandinn verði að leysa hugsun skáldsins undan bragformi frumtextans og fella hana að bragformi býðingarinnar.

Ég reyndi að hafa að leiðarljósi hvaða áhrif Shakespeare virtist vilja að setningarnar í leikritinu hefðu. Hvað eru pessar persónur í rauninni að hugsa pegar pær mæla fram orð sín? Hvað ætla pær sér? Hver er kjarninn? Pannig reyndi ég að vera skáldinu trúr, pótt ég pyrfti eins og áður segir að enduryrkja texta pess til pess að mæta kröfum hins bundna máls og íslenskrar braghefðar.

Um bragarhátt pýðingarinnar ritaði ég grein í leikskrá sýningarinnar sem síðan birtist sem eftirmáli pegar býðingin var gefin út á bók og langar mig hér að tilfæra helstu atriði peirrar umfjöllunar minnar. ${ }^{1}$ Bragarhátturinn sem Shakespeare beitir oftast í Ríkharđi III nefnist blank verse á ensku og hefur verið kallaður stakhenda á íslensku. I stakhendu Shakespeares telur hver lína tíu eða ellefu at-

1 William Shakespeare, Ríkharður III, íslensk pýðing: Kristján Pórður Hrafnsson. Borgarleikhúsið, Reykjavík 2019. 
kvæði, skiptist í fimm stígandi tvíliði og hefur oft áherslulausa endingu á eftir síðasta risi. Stundum víkur skáldið frá pessu og fækkar bragliðunum í hverri línu, t.d. niður í prjá. Bragarháttur pýðingarinnar má kallast íslenskt afbrigði af bragarhætti Shakespeares. Munurinn felst til dæmis í pví að í pýðingunni er beitt stuðlasetningu samkvæmt íslenskri braghefð. Reglulega stuðlasetningu er ekki að finna í texta Shakespeares, ólíkt pví sem tî̉kast í bundnu máli á íslensku. Sú hefð hefur aftur á móti skapast að pegar bundið mál á erlendri tungu er pýtt yfir á bundið mál á íslensku notast pýðendur við stuðlasetningu samkvæmt okkar aldagömlu braghefð. Í pýðingunni er hver braglína sérstuðluð, p.e.a.s. hver braglína hefur tvo stuðla en er ekki tengd við næstu braglínu á eftir með höfuðstaf. Slík stuðlasetning er algeng í íslenskum pýðingum á leikritum á bundnu máli og hafa fyrri pýðendur Shakespeares, t.d. Helgi Hálfdanarson og Pórarinn Eldjárn, gjarnan notað hana. Annar munur á frumtextanum og pýðingunnni er sá að Shakespeare notar stígandi tvíliði í braglínum sínum, en í íslenska textanum er notast við hnígandi tvíliði, og stundum hnígandi príliði. Ástæðan fyrir pessu er áherslulögmál íslenskunnar. Ýmsir bragfræðingar hafa bent á að vegna pess að í íslensku er pyngsta áherslan alltaf á fyrsta atkvæði orðs, sé í raun ekki rétt að gera ráo fyrir stígandi bragliðum í bundnu máli á íslensku. Eðlilegra sé að líta svo á að braglínur á íslensku byggist á hnígandi bragliðum, en geti hafist á forlið eða forliðum án áherslu. Í pessari pýðingu er tvíliðurinn ríkjandi en stundum er blandað saman tvíliðum og príliðum í sömu braglínu. Раð stílbragð að nota pannig ýmist tvílið eða prílið er í samræmi við íslenska braghefð og hafa mörg okkar helstu skáld beitt pví markvisst í ljóðum sínum, svo sem Einar Benediktsson, Tómas Guðmundsson, Jón Helgason, Steinn Steinarr og fleiri. Helgi Hálfdanarson og Pórarinn Eldjárn nota líka stundum príliði í Shakespearebýðingum sínum, pótt tvíliðurinn sé par ríkjandi. Af notkun príliðarins í pýðingu minni leiðir að braglínur hennar hafa gjarnan fleiri atkvæði en braglínur frumtextans, pótt bragliðafjöldinn sé yfirleitt sá sami. Нvað pað varðar er fylgt fordæmi sem skapast hefur en mörg dæmi eru um ólíkan atkvæðafjölda í braglínum pegar bundnu máli á erlendri tungu er snúiðá bundið mál á íslensku. Braglínur Shakespeares í Ríkharłi III ríma yfirleitt ekki en öðru hverju beitir skáldið pó rími til pess að gefa 
orðunum aukinn áhrifamátt. Í pýðingunni er pað viðmið ríkjandi að ríma pegar Shakespeare rímar.

Við vinnu mína var ég alltaf meðvitaður um pað að ég væri að pýða texta til flutnings í leikhúsi en ekki texta til lestrar af bók. Í leikhúsinu hefur áhorfandinn aðeins augnablikið sem setningin hljómar til pess að ná merkingunni. Pegar augnablikið er liðið hljómar næsta setning og svo koll af kolli. Í leikhúsinu er einfaldlega ekki hægt að staldra við, fletta til baka og lesa aftur. Ég reyndi pví að hafa textann skýran. Pýðingin er með öðrum orðum sérstaklega hugsuð til pess að vera leikin og pjóna sviðsetningu Brynhildar Guðjónsdóttur, pótt Borgarleikhúsið hafi svo nokkru eftir frumsýningu gefið textann út á bók.

Með pýðingu minni á Rikharði III leitast ég við að fylgja ákveðinni hefð sem skapast hefur hvað varðar pýðingar á bundnu máli á erlendri tungu yfir á bundið mál á íslensku, og á ég pá ekki aðeins við bundið mál í leikhúsi heldur ljóðapýðingar almennt. Af peim sem varðað hafa veginn og ég leyfi mér að líta á sem nokkurs konar lærimeistara vil ég nefna Magnús Ásgeirsson, Jón Helgason, Helga Hálfdanarson og Pórarin Eldjárn. Helgi Hálfdanarson hefur vissulega ákveðna sérstöðu sökum allra Shakespearepýðinga sinna sem eru mikið prekvirki. Ég hef stundum verið spurður að pví hvernig tilfinning pað sé að pýða að nýju verk sem annar pýðandi, afar mikilsvirtur, hefur býtt. Í pví sambandi langar mig að vísa til orða míns gamla kennara úr Háskóla Íslands, Ástráðs Eysteinssonar bókmenntafræðings, í viðtali við Morgunbladið 29. janúar árið 2018 par sem hann talar um pað að pýðandinn sé í svipuðu hlutverki og tónlistarmaður sem túlki verk annarra. Og mig langar að bæta pví við orð Ástráðs að ný túlkun á lagi, ný útsetning, parf ekki á nokkurn hátt að vera vanvirðing við eldri útsetningar. Hver söngvari eða hljóðfæraleikari hefur sinn stíl og vill kannski gera hlutina eftir sínu höfði án pess að með túlkun sinni vilji hann á nokkurn hátt gera lítið úr túlkun peirra sem á undan komu. Hin nýja túlkun er einfaldlega öđruvísi. Ég lít svo á að hver ný pýðing sé í rauninni ný túlkun. Og ég held að pað sé mikilvægt að við umgöngumst meistaraverk klassískra leikbókmennta af virðingu og trúmennsku, en einnig eins og lifandi efnivið sem gefur ólíkum listamönnum tækifæri til að túlka og skapa á ólíkan hátt. 